\title{
Anja Dular \\ Vloga žensk v črni umetnosti: prve slovenske knjige in zgodovina tiskarstva v Sloveniji
}

Ključne besede: ženske, zgodovina tiskarstva, Slovenija

DOI: $10.4312 /$ ars.9.2.125-143

\section{Uvod}

Predstava o ženskah in njihovi vlogi v družbi, ki je nastala v 19. stoletju, ko so jih skušali prikazati le kot matere, gospodinje in morda zveste vernice, se je projicirala tudi na zgodnejša stoletja. Moderna doba jo je odločno revidirala. Razprave o ženskah $\mathrm{v}$ antiki ter o njihovi pomembni vlogi v srednjeveški družbi in zgodnjem novem veku kažejo na njihov delež na različnih področjih delovanja (Classen, 2007).

V zadnjih desetletjih so se z zgodovino položaja žensk v družbi začeli intenzivno ukvarjati tudi na Slovenskem. Leta 2003 je izšel zbornik o Slovenskem ženskem društvu, ki je delovalo v prvi polovici 20. stoletja. V uvodni študiji je Marta Verginella delovanje te družbe intelektualk postavila $\mathrm{v}$ okvir evropskih gibanj, ki segajo že v 18. stoletje (Verginella, 2003). Prav tako je tematiko in začetke gibanja v uvodnem poglavju dela Slovenke na prehodu v socializem obravnavala Mateja Jeraj (Jeraj, 2005). O začetkih javnega udejstvovanja žensk je pisal Peter Vodopivec in poudaril, da se je v notranjeavstrijskih deželah šele $\mathrm{v}$ šestdesetih letih 19. stoletja uveljavila ideja, naj bo ženskam, bodisi samskim ali vdovam, omogočeno, da se preživljajo same, torej opravljajo različne poklice (Vodopivec, 1994, 36). O problematiki položaja žensk v družbi je bil leta 2004 organiziran simpozij slovenskih zgodovinarjev Ženske skozi zgodovino. Darja Mihelič je opozorila na pomembno prakso, da so že v srednjem in zgodnjem novem veku obrtne pravice večkrat prenašali tudi po ženski liniji, torej ob smrti obrtnika na vdovo ali hčerko (Mihelič, 2004, 28-29). Prav tako Sabine Florence Fabijanec omenja sodelovanje žena dalmatinskih trgovcev pri ključnih odločitvah (Fabijanec, 2004). Žal pa delež žensk v poslovnem svetu obrti in trgovine na Slovenskem še ni bil podrobno obravnavan. Tako primerjalna študija različnih poklicev ni možna. Vlogo žensk v tiskarstvu in knjigotrštvu pa lahko kljub vsemu predstavimo na podlagi ohranjenih arhivskih dokumentov in tiskanih virov. Ker pa 
so bile žene s knjigo povezane tudi kot bralke in ustvarjalke, pred izumom tiska s premičnimi črkami tudi kot prepisovalke, naj mi bo dovoljeno, da uvodoma opozorim tudi na ta segment.

O liku žensk v slovenski književnosti je bilo napisanih več obsežnih razprav. Problem je zanimal že raziskovalce v 19. stoletju (Radics, 1862), z različnih stališč pa so ga obravnavali tudi sodobni slavisti, zgodovinarji in etnologi (Cevc, 1977; SturmSchnabl, 1997-1998; Retl, 2001; Terseglav, 1998). O avtoricah literarnih del, predvsem pesmi, vse do 19. stoletja navadno ne govorimo in še v tem obdobju omenjamo le tri imena, in sicer Josipino Turnograjsko, Pavlino Pajkovo in Luizo Pesjakovo (Borovnik, 1995, 28-34; Mihurko Poniž, 2014).

Več podatkov imamo o ženskah kot bralkah. Pisani viri o tem so ohranjeni že iz 16. stoletja. Primož Trubar je pohvalil kranjske plemkinje, da imajo po svojih gradovih, dvorih in hišah svetopisemske in druge nabožne knjige v nemškem in slovenskem jeziku ter jih ne puste, da bi se prašile, ampak jih berejo otrokom, družini in podložnikom. ${ }^{1}$ V 17. stoletju je ljubljanski knjigotržec Janez Krstnik Mayr prodajal več literarnih del, ki jih je posebej namenil nežnejšemu spolu. V njegovem knjigotrškem katalogu iz leta 1678 že nastopa tako imenovana »Frauenzimmerliteratur «. Na bralke niso pozabili tudi naši trgovci s knjigami v 18. stoletju, saj v reklamnih oglasih in katalogih pogosto omenjajo, katera dela so namenjena prav njim (Dular, 2002).

$\mathrm{Na}$ tem mestu želim opozoriti še na literarno ustvarjalnost žensk na naših tleh, ki sega že v srednji vek. Ne moremo se sicer pohvaliti s pisateljicami, kot sta bili slavni Francozinji Christine de Pizan in Marie de France, a kot prepisovalke in iluminatorke rokopisov so nune v Marenbergu in predvsem Velesovem - njihovo delo je bilo po kvaliteti cenjeno skoraj tako kot sodobno delo iluminatorjev v moških samostanih, npr. Stična (Golob, 1994) - doprinesle pomemben delež k srednjeveški kulturi na Slovenskem (Mlinarič, 1997, 221-229; Pivec Stele, 1971, 90-91).

\section{Tiskarstvo in knjigotrštvo}

S knjigo so v zgodnjem novem veku povezane tri dejavnosti - tiskarstvo, papirničarstvo in knjigotrštvo. Ilustracije v Diderotovi Enciklopediji kažejo, s čim so se ukvarjale žene v papirničarstvu: sortirale so surovino - krpe, razvrščale in gladile papir ter zlagale liste, za kar nista bili potrebni posebna izobrazba in spretnost, ampak predvsem potrpljenje (Coulston Gillispie, 1959, vol. 2, pl. 360-368).

Knjigarne nikakor niso bile zaprti, mirni prostori, namenjeni le bralcem in kupcem knjig. Po ilustracijah, ki jih je v obsežni zbirki upodobitev in tekstov zbral 1 Posvetilu v delu Svetega Pavla listuvi (1567). 
Siegfred Taubert, vidimo, da so bili to prostori, kjer se je poleg prvotnega namena kupovanje knjig - dogajalo še marsikaj. Naj navedem le en primer - Abraham Bosse, francoski slikar in grafik, avtor slike La galerie du Paris (1640), zanjo je dobil navdih po istoimenski Corneillevi komediji, je »dokumentiral« vzdušje v knjigarni v 17. stoletju. Le nekaj posameznikov je prišlo po literaturo, naprodaj pa so bili tudi modni dodatki, pozamenterija, dame so razkazovale obleke in klepetale, moški so našli priložnost za dvorjenje. Po trgovini sta se sprehajala dva negovana psa. Za trgovskim pultom so bili tako moški kot ženske, kar nazorno kaže, da so dame ves čas sodelovale v teh podjetjih, četudi niso bile lastnice (Taubert, 1966). Tudi v naših krajih so v knjigarnah v preteklosti poleg osnovnega artikla prodajali tudi drugo blago. Ljubljanski knjigotržec Ignac Merk je leta 1784 objavil časopisni oglas, v katerem kupce opozarja, da prodaja dišečo vodico in več različnih vrst čokolade. ${ }^{2}$ Stoletje kasneje so posneli podobo knjigarne Josipa Gorenjca v Trstu, kjer je na policah raznovrstno blago, ne le knjige (Waltritsch, 2002, 66).

Dovoljenje za ustanovitev tiskarne je bilo v pristojnosti državne uprave, ki je dodeljevala tudi koncesije za izdelavo črkovnega materiala. Zelo zahtevni so bili tudi pogoji za delo v knjigotrški dejavnosti, stroki, ki je bila skozi vso zgodovino močno povezana s tiskarstvom, saj skoraj ni bilo tiskarja, ki se ne bi ukvarjal tudi s prodajo knjig. Naj torej predstavim, kakšno izobrazbo je moral imeti knjigarnar v 18. stoletju. Po predpisu - Buchhändlerordnung -, ki ga je Marija Terezija izdala 28. marca 1772, je moral uspešno zaključiti določeno učno dobo, poznati literaturo in bibliografijo ter obvladati več jezikov. Za vse knjigotržce je bil obvezen tudi izpit na univerzi (Kropatschek, 1796, 72-77). Teh zahtev vsekakor niso mogle izpolniti ženske, pa jih vendarle najdemo na čelu knjigarn in tiskarn že v zgodnjem novem veku. Obstajalo je namreč pravilo, da so ob smrti tiskarja podjetje z vsemi koncesijami podedovali in prevzeli zakoniti dediči, največkrat vdova (Grabovszki, 2009). Delo s svinčenimi črkami je bilo zdravju škodljivo, to pa je bil glavni vzrok, da so tiskarji umirali razmeroma mladi, zato skorajda ni poklica, kjer bi v preteklosti našli toliko vdov in nato pomembnih žensk, ki so krajši ali daljši čas vodile podjetja - tiskarne in knjigarne. Zgodovinarji njihovega dela niso prezrli. Že v začetku 20. stoletja je izšla razprava Jamesa Ramsayja MacDonalda Women in the printing trades: a sociological study. Lynne Fors je avtorica virtualne razstave o delu žensk - tiskark iz Velike Britanije - Women Printers in Great Britain, 1475-1700, ${ }^{3}$ Albrecht Classen je vzel pod drobnogled njihovo delo v nemškem okolju (Classen, 2000; Classen, 2001), njegov pregled za 16. in 17. stoletje pa želimo tu dopolniti ter opozoriti še na nekatera imena iz kasnejših obdobij.

$2 \quad$ Laibacher Zeitung 2, 1784, št. 28.

3 http://www.library.illinois.edu/rbx/exhibitions/chez_exhibit/index.html, [10. 10. 2014]. 
Kako velik delež v tiskarstvu so imele ženske, lahko ponazorimo tudi s fondi bibliotek, ki imajo objavljene indekse tiskarjev. Na podlagi tiskanih katalogov Britanske knjižnice, zanimali so nas predvsem tiski, povezani $\mathrm{z}$ nemškim in italijanskim kulturnim okoljem, lahko ugotovimo, da je v 16. stoletju v nemških mestih - Frankfurtu, Kölnu, Augsburgu, Nürnbergu, Baslu, Tübingenu, Erfurtu, Ingolstadtu in Trierju - tiskalo vsaj 17 žensk. ${ }^{4} \mathrm{~V}$ naslednjem, 17. stoletju je njihovo število mnogo večje - $116 !^{5}$ Veliko slabše so se odrezale v Italiji, kar moramo pripisati predvsem bolj tradicionalnemu položaju žensk v tamkajšnji družbi, kajti našli smo le dve: Caterino Mayr v Neaplju (1517-1523) in Elisabetto Rusconi v Benetkah (1525-1527). ${ }^{6}$ Pač pa je Classenu prav tako na podlagi kataloga Britanske knjižnice uspelo identificirati 65 dam, ki so tiskale angleške knjige na britanskem otočju, v Parizu in nizozemskih mestih, podatke za nemško govorno področje pa je dopolnil na podlagi katalogov knjižnic v Heidelbergu in Würzburgu (Classen, 2001). Sicer pa so se ženske na tiskih razmeroma redko podpisovale z osebnimi imeni, pogosto so ta izpuščena in je bil natisnjen le priimek, ali pa so zapisane kot vdove tiskarjev. Včasih so se dame tiskarke skrivale tudi za podpisom »dediči« tiskarja oz. v nemščini »Erben«, a teh primerov, kjer ni eksplicitno zapisano, da so bile lastnice ženske, nismo upoštevali. Na podlagi kataloga Britanske knjižnice lahko naštejemo tudi nekaj imen posameznic. Anna Ruegerin je bila na čelu tiskarne v Augsburgu že v času inkunabul (1484). Barbara Cnipius in Maria Steinmayer sta skupaj delali v Frankfurtu. Po nekaj let so v 16. in 17. stoletju tiskarne vodile še sledeče dame, ki niso zapisane le kot vdove, ampak z lastnimi imeni - Agatha Gegler v Augsburgu, Catharina Gerlach, Katharina Dietrich, Maria Sibylle Graff, Kunigunde Hergotin in Katharina Lantzenberger v Nürembergu, Barbara Mayer v Dillingenu, Anna Schuhmann v Pragi, Barbara Sachsin, Martha Hertz in Martha Spangenberg v Erfurtu, Elisabeth Angeraiir in Anna Weissenhorn v Ingolstadtu, Antoinetta Bourignon v Husumu, Anna Berg v Münchnu, Sabina Gerdesius v Leipzigu, Magdalena Haan v Straubingu, Margareta Ising v Frankfurtu na Majni in Anna Franziska Voigt na Dunaju (Classen, 2001, British Library).

\section{Trubar in tiskarka Magdalena Morhart $\checkmark$ Tübingenu}

Prve tiskarne na Slovenskem so delovale v 16. stoletju, njihovo delo je bilo povezano s protestantizmom. Razvejana je bila tudi trgovina s knjigami, saj je bila

4 Short title catalogue of books printed in german speaking countries and german books printed in other countries 1455-1600, London 1962.

5 Catalogue of books printed in the German-speaking countries and of german books printed in other countries from 1601 to 1700, London 1994, vol. 5.

6 Short-title catalogue of books printed in Italy and of Italian books printed in other countries from 1465 to 1600 now in the British Library, London, 1988. 
večina slovenskih knjig tedaj tiskana v Nemčiji. In že v tem zgodnjem obdobju moramo omeniti prvo damo na čelu tiskarne.

Tiskar in založnik Ulrich Morhart je bil rojen v Augsburgu, njegovi prvi tiski so znani iz Strassburga (1519), kasneje se je preselil v Tübingen in tu lahko sledimo njegovi plodni tiskarski produkciji - natisnil je okoli 160 del. Izdajal je dela katoliških in kasneje tudi protestantskih piscev. Na njegovo življenjsko pot pa so v veliki meri vplivale ženske. Že v Strassbourgu si je pridobil meščanske pravice s poroko z Barbaro Burger. V Tübingenu je na enak način postal lastnik hiše (Widmann, 1971, 58). Po njegovi smrti (1554) je tiskarno vodila vdova Magdalena, ki je bila njegova tretja, če ne celo četrta življenjska sopotnica. ${ }^{7}$

Kar 17 slovenskih tiskov iz 16. stoletja (med letoma 1555 in 1567) je bilo natisnjenih v obdobju, ko je bila na čelu tiskarne Morhartova vdova Magdalena. O njej je Primož Trubar v pismu Henriku Bullingerju 10. julija 1557 zapisal: »Tiskarjeva vdova se je toliko pogajala $\mathrm{z}$ mano, da moram 10 ali 12 tednov s svojim delom počivati, češ da mora tiskati nemško retoriko in jo za naslednji frankfurtski sejem izdelati, česar sicer ne bi zmogla, če bi zame tiskala, pa da bi zaradi mojega tiska imela 200 goldinarjev izgube« (Rajhman, 1986, 30-31). Obrt sta ji pomagala voditi sinova iz prvega zakona Jurij in Oswald Gruppenbach, zato je tiskarna v publikacijah navedena z različnimi oznakami: »Apud haeredes Ulrici Morhardi«; »Durch Ulrich Morharts Witfraw«; "Apud viduam Ulrici Morhardi«; "Gedruckt zu Tübingen, bey Ulrich Morharts Wittib «. ${ }^{8}$ Pogosto je naveden le kraj natisa Tübingen (v slovenskih tiskih $v$ Tibingi). Med Magdaleninimi posebnimi dosežki s tiskarskega stališča omenjajo zemljevid, ki ga je izdala leta 1559 - Warhafftige und grundtliche Abconterpheung des loblichen Fürstemthumbs Würtemberg. Sočasno so knjige v slovanskih jezikih izdajali tudi v Urachu, kjer je bila sicer samostojna tiskarna Biblijskega zavoda, vendar so občasno v njej pomagali tudi stavci Magdalene Morhart iz Tübingena (Heiligensetzer, 2008, 24; Widmann, 1971, 63). Magdalena je umrla leta 1574, že 1571 pa je bil na čelu tiskarne njen sin Georg Gruppenbach.

Kdaj smo pozabili, da je Magdalena obstajala, in vse Trubarjeve slovenske tiske iz obdobja med letoma 1555 in 1567 pripisali Ulrichu Morhartu? Že v Simoničevi Slovenski bibliografiji je Ta evangeli svetiga Matevsha (1555) napačno pripisan Ulrichu Morhartu, najbrž zato, ker ima na naslovnici njegov tiskarski znak, ki ga je tiskarna obdržala tudi po lastnikovi smrti. Hkrati je Simonič izpustil navedbo tiskarke »Gedruckt zu Tübingen, bey Ulrich Morharts Wittib« tudi pri publikaciji Register

7 Hans Widmann je o tem nameraval napisati razpravo v Gutenberg Jahrbuchu, a žal tega ni uresničil (cfr. Widmann, 1971, 58).

8 Npr. Register und summarischer Innhalt, aller der Windischen Bücher, die von Primo Trubero, biss auff diss 1561. Jar in truck geben seind. 
und summarischer Inhalt aller der Windischen Bücher (1561) (Simonič, 1903-1905, 297, 537). Nasprotno pa je France Kidrič v Slovenskem biografskem leksikonu jasno zapisal, da je tiskarno vodila Magdalena Morhart in v omenjenem obdobju natisnila vsa Trubarjeva dela (Kidrič, 1933-1952, 154). Tudi Mirko Rupel v temeljnem delu o slovenskem reformatorju Primus Truber navaja, da so bile knjige tiskane pri Morhartovi vdovi, vendar pa v seznamu ne razrešuje tistih del, na katerih tiskar pač ni vpisan (Rupel, 1965, 137, 293-296). Ko smo leta 1968 dobili pregled slovenskega protestantskega tiska izpod peresa Branka Berčiča, je avtor vsem v Tübingenu natisnjenim delom, kjer ni bilo navedeno ime tiskarja, $v$ oglatem oklepaju dodal ime umrlega Ulricha Morharta (Berčič, 1968). Tako je z bibliotekarsko oznako - oglatim oklepajem - opozoril, da je bil podatek o založniku oziroma tiskarju pridobljen izven predpisanih virov, torej ne z naslovnic! Kasneje, ko je Berčičevo delo postalo temeljni priročnik za obdelavo knjig $\mathrm{v}$ slovenskem knjižničnem sistemu (COBISS), so ta pomemben detajl prezrli in Trubarjeva dela iz omenjenega obdobja v celoti pripisali že umrlemu tiskarju Ulrichu Morhartu. ${ }^{9}$ Da se je napaka nato znašla v delih avtorjev, ki so podatke črpali iz Cobissove vzajemne baze, verjetno ni posebno presenečenje (npr. Premk, 1999, 90; Glavan, 1999, 183; Glavan, 2000, 22-53; Glavan, 2003, 40; Stanovnik, 2005, 293; Grdina, 2007; Glavan, 2008).

Kaj je torej botrovalo pomoti, da je Trubarjeve knjige med letoma 1555 in 1567 v Tübingenu tiskal Ulrich Morhart? Deloma je bila temu zanesljivo kriva njegova signeta, ki so jo uporabljali še po smrti. Drugi, morda manj pomemben vzrok, ki je povzročil zmedo, pa je dejstvo, da je imel med letoma 1557 in 1568 v Tübingenu svojo lastno tiskarno tudi Ulrich Morhart mlajši, vendar pa ni bil povezan s slovensko knjižno produkcijo (Berčič, 1968, 37).

Dalmatinovega prevoda Biblije sicer ni tiskala ženska, a pri razširjanju slovenskega Svetega pisma (1584) na Koroškem je sodelovala vdova Margaretha Rosmarin iz Beljaka, prodala je kar 149 izvodov (Dimitz, 1875, 208). Zanimivo je, da je leta $1614 \mathrm{v}$ Ingolstadtu ponatisnila temeljno delo našega rojaka Matrina Pegiusa s področja prava - o služnostih - Dienstbarkhaiten Elisabetha Angermair.

\section{Knjigarke in tiskarke $v$ sedemnajstem in osemnajstem stoletju}

Po letu 1582 so po pravilu Quius regio eius religio morali deželo Kranjsko, današnjo osrednjo Slovenijo, pripadniki nove vere zapustiti. Pod drobnogled so

9 Kot primer pravilne katalogizacije naj omenimo katalog Britanske knjižnice, v katerem je lepo navedeno, da so bili tiski med letoma 1555 in 1570 delo tiskarke - vdove Ulricha Morharta (Shorttitle catalogue of books printed in the German-speaking countries and German books printed in other countries from 1455 to 1600 now in the British Museum, London, 1962, 1107-1108). 
vzeli tudi njihove knjižnice. Nekatere publikacije so uničili, druge razprodali. Na prelomu med 16. in 17. stoletjem je v Ljubljani deloval knjigovez Stefan Beckher. Poleg svojega osnovnega poklica se je ukvarjal tudi s prodajo papirja in knjigotrštvom. Po knjigovezovi smrti (1609) je knjigarno prevzela njegova žena, kar je mogoče sklepati iz notice škofa Hrena, ki pravi, da so bile ob razprodaji Dalmatinove biblioteke heretične knjige predane Beckherjevi vdovi (Radics, 1881, 81). Podatek torej kaže, da so bile že v zgodnjem obdobju tiskarstva tudi ženskam zaupane pomembne naloge pri prodaji in ocenjevanju knjig.

Po večdesetletni stagnaciji v razvoju tiskarstva na Slovenskem predstavlja prelomnico šele leto 1678. Deželni stanovi so namreč dve leti prej sklenili, da bo v Ljubljani ponovno začela delovati tiskarna. Tiskarju so odobrili pravno zaščito in letno podporo 200 goldinarjev. Nalogo, da poišče primernega obrtnika, so zaupali duhovniku, teologu in zgodovinarju Janezu Ludviku Schönlebnu. Schönleben je na Kranjsko pripeljal salzburškega tiskarja Janeza Krstnika Mayrja, ki je v Ljubljani ustanovil podružnico svojega že uveljavljenega podjetja. Ukvarjal se je tudi s knjigotrštvom, kar je mogoče razbrati iz njegovega ljubljanskega knjigotrškega kataloga iz leta 1678. Po letu 1682 je ljubljansko podjetje prevzel Jožef Tadej Mayr, ki pa je že leta 1695 umrl. To je bil čas, ko je bila v Ljubljani ustanovljena Academia operosorum (1693), prvo znanstveno društvo na Kranjskem, organizirano po vzoru drugih evropskih združenj baročnega obdobja. Dela njenih članov - pravnikov, teologov in zdravnikov - je tiskala in zalagala Mayrjeva tiskarna. Mayr je kot knjigotržec skrbel tudi za to, da so v knjižnice operozov prišle novosti z različnih znanstvenih področij, ki so bile tiskane širom Evrope (Dular, 2002, 116-124).

Tem smernicam je sledila tudi Ana Barbara Mayr, vdova Jožefa Tadeja Mayrja. $\mathrm{Na}$ čelu tiskarne je vztrajala celo desetletje (vse do leta 1705), ko je podjetje prevzel sin Janez Jurij. Ana Barbara Mayr velja za prvo tiskarko na Kranjskem in prav pod njenim vodstvom je podjetje doseglo velik razvoj (Dular, 2002, 125-130).

Med pomembnejšimi tiski iz njenega obdobja naj omenim tretji (1696) in četrti (1700) zvezek verskega priročnika Sacrum promptuarium (prva dva sta bila natisnjena v Benetkah v delavnici Zacharija Conzattija). Avtor Janez Svetokriški se najbrž ne bi odločil za zamenjavo tiskarne, če bi ne bila kvalitetna. Tehnično zahtevno delo je bil tudi natis pravil Academie operosorum in seznama vseh njenih članov (Apes Academicae Operosorum Labacensium, 1701). Knjiga je namreč bogato opremljena $s$ heraldičnimi znamenji in alegorijami. Nadalje je natisnila več njihovih del, med drugim prve tri zvezke Chronologiae Medicae (1699, 1700 in 1702) zdravnika Marka Gerbca in razpravo s področja politične ekonomije Bos in lingua sive Discursus academicus de pecuniis vetero-novis (1695), ki jo je napisal Ivan Štefan Florjančič 
Grienfeld. Iz Mayrjeve tiskarne je prišla tudi obsežna teološka razprava Italijana Pietra Locatellija (Exorcismi potentissimi et efficaces, 1698).

V času, ko je bila na čelu podjetja Ana Barbara Mayr, je v knjigah tiskarna največkrat označena le s priimkom: npr. »Typis Haeredum Mayr«; »ex Typographéo Mayriano«; »ex typographio Mayriano«; »Mayrische Druckerey«. Le v dveh znanih primerih je na naslovnici natisnjeno polno ime lastnice (»Buchdruckerin Anna Barbara Märin (Mayrin)« oz. »typis Annae Barbarae Mayrin«). ${ }^{10}$

Zadnji predstavnik tiskarske družine Mayr je bil Janez Jurij. Okoli leta 1730 je od njega tiskarno kupil Adam Friderik Reichard. Ko je Reichard leta 1757 umrl, je podjetje, še vedno edino tiskarno v deželi, podedovala njegova vdova Ana Elizabeta Reichard. Tiskarno in knjigarno je vodila dve leti in bila $\mathrm{v}$ tem času tudi uradna deželna tiskarka. To lahko razberemo iz naslovnic knjig, kjer se je v slovenskih izdajah podpisala »U'Lublani, Per Annae Elisabethae Raichhardtouke, Uvedove«, v nemških »Laybach, gedruckt bey Anna Elisabetha Reichhardtin, Wittib«, v italijanskih pa »Lubiana: stampato da Anna Elisabetha Reichhardtin«. Tiskala je $\mathrm{v}$ štirih jezikih, in sicer slovenščini, nemščini, latinščini in italijanščini. Kot zanimivost naj omenimo še to, da se prav v njenem času na naslovnicah pojavijo pripombe, ki opozarjajo na kvaliteto prevodov in novih izdaj. Večkrat namreč srečamo pripis, da je delo »skrbno preloženo « ali da gre za drugo, v boljšem jeziku pripravljeno izdajo.

Ana Elizabeta Reichard je tiskala tudi molitvenike in verske priročnike za preprosto ljudstvo. Omeniti velja še dvojezična italijansko-nemška dramska besedila, ki so jih natisnili ob gostovanjih tujih dramskih skupin, da bi gledalcem omogočili lažje razumeti dogajanje na odru. Tako je leta 1757 v Ljubljani izšlo Goldonijevo delo L'impero delle donne: dramma giocoso per musica da rappresenatarsi nell' augusta citta di Lubiana.

Tujci, ki so skozi stoletja obiskovali našo deželo, so se zelo zanimali za Kras in njegove pojave. Med znamenitosti sodi tudi presihajoče Cerkniško jezero, ki ga je leta 1758 temeljito opisal Franz Anton Steinberg. Monografija Gründliche Nachricht von dem in dem Inner-Crain gelegenen Czirknitzer See: worinn alle Seltenheiten desselben auf das genaueste aufgeführet und zu mehrerer Deutlichkeit mit verschiedenen Kupfern erkläret werden je bogato ilustrirana z bakrorezi, zato je bilo delo tiskarne, ki jo je tedaj vodila Ana Elizabeta, zelo zahtevno (Dular, 2002, 135). Zanimivo je, da je tri

10 Zorattus, J., Memorabilia orbis, et urbis Goritiensis ... dedicata honoribus ... domini Ferdinandi, Dei gratiâ episcopi Labacensis ... et sub philosophicis thesibus in caesareo Societatis Jesu gymnasio Goritiae propugnata â... Joanne Zoratto anno post Christum natum M.D.CCIV ... praeside r. p. Joanne Baptista Thullner ... Labaci: typis Annae Barbarae Mayrin. 
leta kasneje ista knjiga »izšla« še v založbi Josepha Moritza v Gradcu, ${ }^{11}$ vendar pa ne moremo govoriti o novi izdaji, saj je bila na novo natisnjena le prva pola, medtem ko so bile ostale prevzete iz tiskarne Elisabethe Reichard v Ljubljani. Dokaz je natančna analiza tipografije obeh izdaj. Steinbergovo delo je bilo tako odmevno, da je že leta 1761 v Bruslju izšla skrajšana francoska verzija (Le lac merveilleux, ou Description du lac de Czirknitz en Carniole, et de ses principales singularités phisiques / tirée de l'Allemand. A Bruxelles: de l'Imprimerie Royale, 1761). Kot zanimivost naj omenimo še to, da jo je Steinberg posvetil grofici Cobenzel in ne njenemu možu, ki se ga je spomnil v posvetilu nemške izdaje.

Leta 1759 je ljubljansko tiskarsko podjetje od Ane Elizabete Reichard kupil Janez Jurij Heptner. Tudi ta je kmalu umrl in nasledila ga je žena Maria Theresia, ki pa v črni umetnosti ni pustila vidnejših sledi. Leta 1765 se je poročila $z$ Janezom Friderikom Egerjem, ki je nato delo v tiskarni uspešno nadaljeval vse do konca 18. stoletja.

V ženskih rokah je bila od leta 1794 tudi druga ljubljanska tiskarna, ki jo je dvanajst let poprej (1782) kot podružnico svojega podjetja v Celovcu ustanovil Ignac Alojz Kleinmayr. Vendar pa Tekla Kleinmayr na razvoj tiskarstva na Kranjskem ni vplivala, saj je dala podjetje v najem. Isto lahko zapišemo za Marijo Terezijo Eger ter Marijo in Frančiško Retzer, ki so na začetku 19. stoletja za krajši čas vodile ljubljanske tiskarne (Berčič, 1968, 124).

\subsection{Podjetnost Rozalije Eger}

Pač pa je imela veliko vlogo v razvoju tiskarske dejavnosti na Kranjskem v 19. stoletju Rozalija Eger (Dular, 2009). Rojena je bila okoli leta 1788. Po moževi smrti (1829) je prevzela podjetje in ga formalno vodila vse do konca življenja 1871 . Na tiskovinah se je kot tiskarka podpisovala s polnim imenom - »Rosalia Eger«, včasih je okrajšala krstno ime ali tiskarno poimenovala le »Eger'sche«. Le v letih 1854-1860 je podjetje nosilo dvojno ime - »R. Eger \& Sohn«, oziroma v slovenskih tiskih »R. Eger in sin«, kajti v tem času je bil njen družabnik sin Franc Ksaver. Žal je že leta 1860 zaradi jetike umrl. Iz časopisne notice lahko razberemo, da je bila $v$ tistem času vodja mestne tiskarne še vedno sedemdesetletna Rozalija Eger, a sinu je bilo ob smrti že 39 let. ${ }^{12}$ Egerjeva je imela pomembno vlogo tudi v družabnem življenju dežele. Bila je članica Kazinskega društva (Casino Verein), čeprav so bili vanj večinoma včlanjeni možje kot pripadniki višjega sloja takratne družbe. Ob njenem imenu najdemo pripis »Buchdruckei Besitzerin«, medtem ko je pri drugih damah zabeleženo le to, da so

11 Gründliche Nachricht, von dem in Inner-Crain liegenden Czirknizer-See. Grätz: in Verlag bey Joseph Moritz Lechner ... : gedruckt bey den Widmanstätterischen Erben, 1761.

Laibacher Zeitung 79, 1860, št. 143 (23. 6.), str. 572. 
vdove pomembnih mož. Egerjevo srečamo tudi med ustanovniki Slovenske matice. Leta 1867 so bile v tem slovenskem znanstvenem društvu, ki je štelo 394 članov, le tri ženske: graščakinja Josipina Greselj, pesnica Luiza Pesjakova in lastnica »tiskalnice in kamnotisne naprave« Rozalija Eger.

Leta 1832 so namreč začeli v Ljubljani uporabljati nov postopek litografije. Delavnico so uredili v tiskarni Rozalije Eger. Čeprav naj bi bili v podjetju soudeleženi tudi ostali trije takratni tiskarji (Jožef Blaznik, Ignac Kleinmayr in Rudolf Milic), pa na tiskovinah - kamnotiskih - prvega obdobja najdemo le ime Rozalija Eger. ${ }^{13}$

Rozalija Eger je tiskala v treh jezikih - nemščini, slovenščini in za potrebe cerkve tudi v latinščini. Črkovni nabor je obsegal več variant, od latinice in nemške gotice pa vse do bohoričice, metelčice in gajice, $\mathrm{v}$ katerih so tiskali slovenska besedila.

V 30. in 40. letih 19. stoletja je za deželne oblasti tiskala različne plakate, razglase in uradne obrazce, ${ }^{14}$ zato so podjetje poimenovali »Eger'sche Gubernial-Buchdruckerei«. Denarne vsote, ki jih je Rozalija Eger prejemala za tiskovine, kažejo, da naklade niso bile majhne. ${ }^{15}$ Verski teksti so bili povezani s cerkvenim obredjem, katoliškimi prazniki in versko vzgojo. ${ }^{16}$ Največ je natisnila krajših verskih besedil v slovenščini, ${ }^{17}$ poleg tega pa tudi obsežne priročnike. ${ }^{18}$ Za katoliško cerkev je natisnila tudi nekaj latinskih priročnikov, ${ }^{19}$ poleg tega pa tudi knjige za podporo slovenskih misijonarjev v Ameriki. ${ }^{20}$

13 Rihar, G., Vishe sa druge bukvize svetih pesem od Bl. Potozhnika, zhveteroglasno v note postavljene od Gr. Riharja. Pri Egerji v Lj. na kamen natisnjene, 1844.

14 Npr. Deželni zakonik in vladni list za kranjsko kronovino = Landes-Gesetz- und Regierungs-Blatt für das Kronland Krain je tiskala od leta 1849 do 1872.

15 Tako so ji na primer leta 1848 izplačali kar tri honorarje, in sicer februarja 929, julija 1090 in jeseni še 154 goldinarjev (AS 14 - Arhiv Republike Slovenije, Gubernij v Ljubljani, 1784-1849, Reg. VIII, fasc. 1, št. 3).

16 Molitvene bukvice za otročiče, 1860; Bodi moj naslednik: molitevne bukve za mladost in odrašene ljudi, 1860; Steza v sveti raj, 1869.

17 Npr.: Albrecht, A., Şveti véliki teden ali molitve in zeremonije, ki se po sapovedi katolshke zerkve véliki teden opravljajo, 1829; Volc, J., Pridige ob posébnih perloshnostih, 1848; Metelko, F., Raslaganje şvetiga evangelija ș. Matevsha, 1849.

18 Npr. Veriti, F., Kerşhanşki katolşhki nauk sa odrashene ljudí, 5 zv., 1834.

19 Klofutar, L., Commentarius in tria priora evangelia / ex optimis cum antiquis tum recentioribus interpretibus, 1858.

20 Şerzé ali Şposnánje in sbóljshanje zhlovéshkiga serzá..: k' pridu osnanovavzam s. vére v'Ameriki, 1847, 1848 in ponovno 1851 ter Bratovșhina s. Leopólda, $k^{\prime}$ pomózhi misijonarjam, to je poslanim osnanovavzam kershanske katolshke vére v' Ameriki, 1833. 
S področja kulturne zgodovine naj omenimo natise del Henrika Coste, ${ }^{21}$ prvega turističnega vodnika po Ljubljani, njeni okolici in Kranjski izpod peresa G. Dzimskega ${ }^{22}$ ter pregleda zgodovine Kranjske, ki sta ju napisala P. Radics in J. Trdina. ${ }^{23}$ Rozalija Eger je natisnila tudi obsežni in s tiskarskega stališča zahtevni deli, krajevni leksikon Kranjske z navedbami gradov, dvorcev in posesti ${ }^{24}$ ter bogato ilustrirano Freyerjevo delo o živalstvu Kranjske, ${ }^{25}$ ki mu je dodan tudi seznam imen v latinščini, nemščini in slovenščini. Aktualni so bili medicinski priročniki za babištvo, knjige o koleri in obsežna Slovenska kuharica. ${ }^{26}$

Tiskarna Rozalije Eger je tiskala tudi dramska besedila in povesti domačih avtorjev ter prevode nemških piscev Schillerja, Schmida in Hoffmanna. S tehničnega stališča so bili še posebej zahtevni glasbeni tiski. Tiskarna Rozalije Eger je imela prednost pred ostalimi ljubljanskimi tiskarji, ker je bila v njenih prostorih litografija. Pripišemo ji lahko okoli petdeset glasbenih del, vsa pa so bila izdelana v kamnotiskarnici oz. na kamen natisnjena pri Egerji. Glasbeni tiski so po obsegu zelo različni - od posameznih listov, kjer je bila natisnjena le ena pesem, do obsežnih zbirk narodnih in cerkvenih pesmi ter skladb, namenjenih šolarjem in društvom. Najobsežnejše so maše in operna dela, med drugim je natisnila Försterjevega Gorenjskega slavčka.

Med zahtevnejše tiske sodijo učbeniki za najmlajše, saj so morali biti bogato ilustrirani. ${ }^{27}$ Tej populaciji je bil namenjen prvi tednik - časopis Vedež, ki ga je urejal Janez Navratil, Rozalija Eger pa je bila tiskarka in založnica. Namenjen je bil predvsem mlajšim in preprostim ljudem, v njem so objavljali pesmi, povesti, zanimivosti o tujih ljudstvih, zgodbe iz živalskega sveta, pa tudi smešnice in uganke. Kasneje je izdajala še dva časopisa - Mladiko in Vrtec, prav tako namenjena najmlajšim. Tiskala je še politični in gospodarski list Naprej (1863) ter nemško pisan tednik Kranjske eskomptne družbe - Laibacher öffentlicher Anzeiger der Laibacher Escompte - \& conc Privat-Geschäftsvermittlungs- Anstalt (1868 do 1869). Prav v vsaki hiši na Kranjskem pa naj bi imeli pratiko. Tako je med letoma 1832 in 1850

21 Costa, E. H., Reiseerinnerungen aus Krain, 1848; Costa, E. H., Krain und Radetzky, 1860.

22 Dzimski, G., Laibach und seine Umgebungen : nebst einer Beschreibung der interessantesten Punkte in Krain, 1860.

Radics, P., Geschichte Krain's, 1862; Trdina, J., Zgodovina slovenskega naroda, 1866.

24 Alphabetisches Verzeichniß der Namen aller Ortschaften, Schlösser, Gütter und Höfe im Herzogthume Krain, 1854.

25 Freyer, H., Fauna der in Krain bekannten Säugethiere, Vögel, Reptilien und Fische, 1842.

26 Pachner, B., Bukve sa uzhénke porodnizharstva, 1848; Potočnik, B. Kolera, 1831; Slovenska kuharica, 1868.

27 Tomšič, I., ABC v podobah in besedi, 1869; Krajnc, J., Mali Blaže v pervi šoli, Kako se hitro brati uči, 1850; Mala slovenska abezedniza starimi in novimi zherkami sa tiste, kteri se hozhejo sami branja nauzhiti, 1852. 
Rozalija Eger izdajala Novo Pratiko, vendar je morala zaradi nasprotovanja in tožbe tiskarja Jožefa Blaznika delo opustiti.

Rozalija Eger je v svojih dveh hišah na Špitalski ulici prodajala tudi knjige, časopise in tiskovine. ${ }^{28}$ Večino publikacij pa je tiskala za druge ljubljanske založnike in knjigarnarje. Tako je v prvi polovici 19. stoletja sodelovala z Adamom Henrikom Hohnom, Janezom Klemensom (Lukman, 1928, 462) in Leopoldom Kremžarjem. Po letu 1850 sta njene tiske prodajala in zalagala Matija Gerber (Šlebinger, 1926, 208) in Janez Giontini (Šlebinger, 1926, 213).

Po smrti Rozalije Eger je lastnica tiskarne postala njena pastorka Leopoldina, ki pa je že leta 1872 umrla. Tako je podjetje dedovala Julijana Materne (roj. Eger) in ga dala v upravljanje Antonu Kleinu in njegovemu družabniku Ivanu Kovaču (Berčič, 1968, 133). Na tiskovinah so še do leta 1883 ob njunih imenih občasno natisnili tudi priimek »Eger-Klein in Kovač (Eger)«.

\subsection{Novomeška tiskarka Marija Tandler}

Podobno vlogo je imela v Novem mestu tiskarka Marija Tandler, ki je po smrti moža Henrika tiskarno vodila dobrih deset let (1836-1848, do sinove polnoletnosti) (Tončič, 1989, 40). V tem času je natisnila nekaj priložnostnih publikacij ${ }^{29}$ ter dve knjigi nabožnega pisca in duhovnika Franca Veritija. ${ }^{30}$ Seveda pa so bili tiski novomeške tiskarne bolj skromni, saj so bili namenjeni predvsem potrebam lokalnega prebivalstva. Tiskala je tudi šolska poročila novomeške gimnazije. ${ }^{31} \mathrm{~V}$ upanju na zaslužek je Marija Tandler poskusila postaviti na noge tudi prvi dolenjski časnik Slovenia. Žal je maja 1848 izšla le poizkusna številka. Ker zgolj s tiskarstvom v Novem mestu ni bilo mogoče preživeti, je Tandlarjeva odprla tudi knjigarno in papirnico. Trgovina ji je zaradi gimnazijcev verjetno prinašala več zaslužka kot tiskarna.

\subsection{Ali so imele ženske - tiskarke, knjigarke in založnice - na Slovenskem enak položaj kot njihovi moški kolegi?}

Analiza nekaterih podrobnosti kaže, da moramo na to vprašanje odgovoriti negativno. Ko je Mayrjevo tiskarno v Ljubljani prevzela Ana Barbara, ji je deželna uprava leta 1697 znižala letno podporo in celo ukinila finančno pomoč pri izdajanju

28 Npr. Kmetijske in rokodelske Novice, 6/1848, Dokladni list 26 (20. 12.), str. 56; Novice 29, 1871, št. 14 (5. 4.), str. 113.

29 Hueber, K., Carniolia per mertvini Franza perviga Tita svojiga v' Aemoni, 1837.

30 Veriti, F., Premishljevanje terpljenja in smerti Gospoda in Odreshenika nashiga Jesusa Kristusa, 1845 in Mnogi sveti nauki in sreki is bukev Pripovist, Pridgarja, Modrosti in Şirah, 1846.

31 Juventus Caes. Reg. Gymnasii Rudolphswertensis ex Moribus et Progressu in Litteris censa exeunte Anno scholastico. 
koledarjev (Dular, 2002, 128). Vzrok naj bi bilo manj kvalitetno delo, v kar pa lahko resno dvomimo, saj je, kot smo navedli zgoraj, prav Ana Barbara od beneške tiskarne prevzela nadaljevanje zelo zahtevnega tiska obsežnega priročnika Sacrum promptuarium, pa tudi sicer je tiskala tehnično zahtevna dela.

Negativen odnos do tiskarn, ki so jih vodile ženske roke, opažamo tudi v kasnejših stoletjih. Ko je Ana Elizabeta Reichard leta 1758 natisnila razkošno ilustrirano knjigo o Cerkniškem jezeru, je bil to s tiskarskega stališča brez dvoma pomemben dosežek. Ko je tri leta kasneje od nje že natisnjene pole prevzel Joseph Moritz iz Gradca, jih je prodajal kot lastno graško izdajo, čeprav je, kot smo že omenili, sam natisnil le prvo polo.

Drug pomemben element, ki kaže na ignoriranje ženske na čelu tiskarne, pa so tiski iz leta 1757.

V Trattnerjevi tržaški tiskarni so leta 1757 natisnili Compendium ritualis Labacensis, cum appendice Germanica, et Carniolica, obredni priročnik, ki ga je sestavil teološki pisatelj Lovrenc Pogačnik. Latinsko besedilo ima v dodatku na osemnajstih straneh litanije in molitve v slovenščini. Istemu avtorju pripisujejo še dve drugi besedili - Missae propriae dioeceseos labacensis in Dioecesarum labacense. Navedeni teksti so povezani z delom ljubljanske škofije, izšli pa so v Trstu leta 1757. Zakaj se avtor ni obrnil na kranjske tiskarje, ni mogoče ugotoviti, verjetno je bil vzrok tej nenavadni potezi, da je tedaj ljubljansko tiskarno vodila predstavnica nežnejšega spola - Ana Elizabeta Reichard (Dular, 2007).

Zanimivo pa je, da lahko navedemo tudi graški tisk iz sredine 18. stoletja Andohtlive Pejsme na use taile s. Mashe (1756). Delo je bilo prav tako namenjeno predvsem prebivalcem osrednje Slovenije, vzrok, zakaj ni bilo tiskano v Ljubljani, pa je bil verjetno enak - na čelu ljubljanske tiskarne je bila ženska. Tiskanje knjig, namenjenih prebivalcem v osrednji Sloveniji, v Gradcu oziroma Trstu je bilo nesmotrno, saj so s prevozom nastali nepotrebni stroški.

Brez težav ni obvladovala tiskarskega dela in moške konkurence na tem področju niti podjetna Rozalija Eger, čeprav so se na njeno stran večkrat postavile deželne oblasti. Kot primer naj omenimo spor, ki ga je imela z Jožefom Blaznikom. Ta si je nameraval urediti lastno litografsko delavnico, čeprav je skupna, za katero je nekaj sredstev primaknila tudi dežela, že delovala v sklopu Egerjeve tiskarne. ${ }^{32}$ Prav tako Jožef Blaznik ni uspel s tožbo, da Egerjeva ponatiskuje njegove pratike, saj je mestna uprava ugotovila, da ne gre za ponatise, ampak za podobno obravnavanje iste tematike. Da bi si za pratike pridobil monopol, je moral Blaznik ostalim trem ljubljanskim tiskarjem

32 V sklopu aktov je tudi argumentacija policijskega direktorja Franza Uhrerja, ki je poudaril, da je v Ljubljani že litografska delavnica, in sicer deluje v tiskarni Rozalije Eger. 
plačevati letno po 100 do 250 goldinarjev, s čimer so se ti odpovedali tiskanju teh najbolj razširjenih in donosnih publikacij (Logar, 1959, 53).

Zanimivo je tudi to, da so ženskam sicer dovolili vodenje tiskarn, do članstva v združenjih tiskarjev pa niso bile upravičene. Ko so bila februarja 1868 potrjena Pravila društva lastnikov tiskarn na Kranjskem, se je na prvem občnem zboru v poslopju realke zbralo 32 članov. Med njimi so bili možje, ki so bili tesno povezani s tiskarno Rozalije Eger - nekdanja učenca in takrat sodelavca Martin Jelovšek in Janez Krajec ter dolgoletni vodja Rozalijine tiskarne Anton Klein, ki je postal tudi prvi predsednik društva. Kakor je zapisano v kroniki društva, se je ustanovnim članom kmalu priključilo še 26 članov, med njimi tudi tiskar Jožef Blaznik (Štrekelj, 1939, 8). Rozalija Eger je bila torej vsaj posredno zastopana že ob sami ustanovitvi društva, kot ženska pa v njem ni mogla sodelovati. Podobno je bilo tudi drugod. Verjetno je bilo v preteklosti bolj malo dejavnosti, v katerih bi uspešno delovalo toliko žensk (predvsem vdov), kot je tiskarstvo, pa so vendarle ostale pred vrati profesionalnih društev. Prvo združenje tiskark je bilo ustanovljeno šele leta 1876 v Angliji.

Tiskarstvo in knjigotrštvo sta specifični gospodarski panogi, ki sta podvrženi ekonomskim zakonitostim, obenem pa zahtevata tudi posebna obrtna in intelektualna znanja. Zato je logično, da so v preteklosti za ti dve dejavnosti veljala posebna določila - vsakdo ni mogel postati tiskar in knjigotržec. Ne nazadnje je hotela tudi oblast imeti nadzor nad razširjanjem informacij, ki so bile vse do 20. stoletja izključno v domeni tiskanih medijev. Kljub vsemu pa so tudi v teh strokah veljala pravila o dedovanju obrtnih dovoljenj in pravic. Podedovale so jih lahko tudi ženske ter nato vodile podjetja, čeprav formalno niso mogle izpolnjevati določil o zahtevani izobrazbi in znanjih. Tako so bile v primerjavi $\mathrm{z}$ drugimi poklici celo privilegirane, obenem pa lahko sklepamo, da kljub temu, da jim ni bil omogočen študij na univerzah, njihovo znanje ni bilo majhno. Ker pa so pogosto tudi kot vdove uporabljale tiskarske signete umrlih mož in se niso podpisovale z lastnim imenom, pomena žensk v zgodovini te dejavnosti niso posebej obravnavali.

Tiskarne pod ženskim vodstvom niso delovale slabše, izgovori oblasti za krčenje finančnih podpor so bili pač del splošnih trendov. Ne moremo pa govoriti o zatajenih tiskarkah, le površnost nekaterih sodobnih raziskovalcev je prezrla njihovo delo v stroki, ki po miselnosti sodi med tako imenovane moške poklice.

Izpostavila sem nekaj posameznic, ki so delovale kot tiskarke na Slovenskem, oziroma so bile povezane s slovenskimi knjigami. V pregledih, ki so bili doslej objavljeni o tej tematiki, namreč naš prostor ni bil upoštevan. 


\section{Literatura}

Berčič, B. (ur.), Abhandlungen über die slowenische Reformation: Literatur, Geschichte, Sprache, Stilart, Musik, Leksikographie, Theologie, Bibliographie. (Geschichte, Kultur und Geisteswelt der Slowenen; Bd. 1), München 1968.

Berčič, B., Tiskarstvo na Slovenskem: zgodovinski oris, Ljubljana 1968.

Borovnik, S., Pišejo ženske drugače?, Ljubljana 1995.

Cevc, A. in drugi, Ženska v slovenski sliki in pesmi, Zagreb 1977.

Classen, A., Frauen als Buchdruckerinnen im deutschen Sprachraum des 16. und 17. Jahrhunderts, Gutenberg Jahrbuch 75, 2000, str. 181-195.

Classen, A., Frauen im Buchdruckergewerbe des 17. Jahrhunderts, Gutenberg Jahrbuch 76, 2001, str. 220-236.

Classen, A., The power of a woman's voice in medieval and early modern literatures, Berlin, New York 2007.

Coulston Gillispie, C. (ur.), A Diderot pictoral encyclopedia of trades and industry, New York 1959.

Dimitz, A., Geschichte Krains III, Laibach 1875.

Dular, A., Živeti od knjig; zgodovina knjigotrštva na Kranjskem do začetka 19. stoletja, Ljubljana 2002.

Dular, A., Rozalija Eger - pomembna, a premalo znana ljubljanska tiskarka, v: $V$ zlatih črkah v zgodovini (Kronika, Izredna številka). Ljubljana 2009, str. 401-412.

Dular, A., Dunajski tiskar, založnik in knjigotržec Johann Thomas Trattner in slovenski knjižni trg 18. stoletja, Kronika 55, 2007, 1-12.

Fabijanec, S. F., Gospodarska djelatnost žena na dalmatinskom komunalnom području od XIV. do XVI. stoljeća. v: Ženske skozi zgodovino: zbornik referatov 32. zborovanja slovenskih zgodovinarjev (ur. Žižek, A.), Celje 2004, str. 49-64.

Grdina, I. (ur.), Primož Trubar: študije k zbranim delom I-IV, Ljubljana 2007.

Glavan, M., Vergerijeva dela $\mathrm{v}$ zbirki protestantik v NUK in drugih evropskih knjižnicah, Acta Histriae 8, 1999, 173-190.

Glavan, M., Prve slovenske knjige. Slovenski reformacijski tiski v izvirnikih in v ponatisih, Ljubljana 2000.

Glavan, M., Slovensko slovstvo v rokopisih in knjigah, v: Zakladi Narodne in univerzitetne knjižnice v Ljubljani, Ljubljana 2003, str. 34-55.

Glavan, M., Slovenski faksimile v 19. in prvi polovici 20. stoletja: predmoderni faksimile, Knjižnica 48, 2004, št. 4, str. 7-36. 
Glavan, M., Trubarjev Album, Ljubljana 2008.

Grabovszki, E., Der Buchhändler als Rechtssubjekt, v: Kommunikation und Information im 18. Jahrhundert: das Beispiel der Habsburgermonarchie (ur. Frimmel, J., Wögerbauer, M.), Wiesbaden 2009, str. 153-161.

Grdina, I. (ur.), Primož Trubar: Študije k zbranim delom I-IV, Ljubljana 2007.

Golob, N., Stiški rokopisi iz 12. stoletja = Codices Sitticenses saeculi XII, Ljubljana 1994.

Heiligensetzer, L., Proti Carigradu - južnoslovanska tiskarna v Urachu, v: Trubarjev in Ungdadov dar Evropi (ur. Glavan, M.), Ljubljana 2008, str. 20-27.

Jeraj, M., Slovenke na prehodu v socializem, Ljubljana 2005.

Kidrič, F., Morhart, tübingenska tiskarska rodbina, Slovenski biografski leksikon 2, Ljubljana 1933-1952, str. 154.

Logar, J., 130 let Blasnikove tiskarne, Ljubljana 1959.

Lukman, F., Klemens, Slovenski biografski leksikon 1. Ljubljana 1925-1932, str. 462463.

Mihelič, D., Žena v predkapitalističnem obdobju na Slovenskem, v: Ženske skozi zgodovino: zbornik referatov 32. zborovanja slovenskih zgodovinarjev (ur. Žižek, A.), Celje 2004, str. 23-30.

Mihurko Poniž, K., Zapisano z njenim peresom, Nova Gorica 2014.

Mlinarič, J., Marenberški dominikanski samostan 1251-1782, Celje 1997.

Pivec-Stelè, M., Srednjeveške knjižnice v Sloveniji, Knjižnica 15, 1971, str. 87-97.

Premk, F., Medsebojni ustvarjalni vplivi Primoža Trubarja in Petra Pavla Vergerija ml., Acta Histriae 8, 1999, str. 61-90.

Radics, P. v., Die Frauen in der Sage und Geschichte Krain's: kulturgeschichtliche Studie, Laibach 1862.

Radics, P. v., Geschichte des deutschen Buchhandels in Krain, Archiv für Geschichte des deutschen Buchhandels 6, 1881, str. 73-93.

Rajhman, J., Pisma Primoža Trubarja (Korespondence pomembnih Slovencev 7), Ljubljana 1986.

Ramsay MacDonald, J., Women in the printing trades: a sociological study, London 1904.

Retl, L., Podoba ženske pri Paolu Santoninu, Zgodovinski časopis 55, 2001, str. 375-383.

Rupel, M., Primus Truber, München 1965.

Simonič, F., Slovenska bibliografija I, Ljubljana 1903-1905.

Stanovnik, M., Slovenski literarni prevod 1550-2000, Ljubljana 2005. 
Sturm-Schnabl, K., Ženska kot avtorica in lik v novejši slovenski književnosti, Jezik in slovstvo 43/3, 1997-1998, str. 97-108.

Šlebinger, J., Gerber Matija, Slovenski biografski leksikon 1. Ljubljana 1926, str. 208.

Šlebinger, J., Giontini Janez, Slovenski biografski leksikon 1. Ljubljana 1926, str. 213.

Štrekelj, A., Organizacija grafičnega delavstva v Sloveniji. Ljubljana 1939.

Taubert, S., Bibliopola: Bilder und Texte aus der Welt des Buchhandels = Pictures and texts about the book trade = Images et textes sur la librairie I-II, Hamburg 1966.

Terseglav, M., Podoba ženske v belokranjskem ljudskem pesništvu, Traditiones 27, 1998, str. 47-59.

Tončič, L., Tiskarstvo na Dolenjskem, Novo mesto 1989.

Waltritsch, M., Oglaševanje slovenskih tržaških trgovcev = Le inserzioni dei commercianti sloveni triestini, Opčine 2002.

Verginella, M., Mesto žensk pod steklenim stropom, v: Splošno žensko društvo: 19011945 (ur. Budna Kodrič, N., Serše, A.), Ljubljana 2003, str. I-VIII.

Vodopivec, P., Kako so ženske na Slovenskem v 19. stoletju stopale v javno življenje, Zgodovina za vse 1, 1994, 2, str. 30-44.

Widmann, H., Tübingen als Verlagsstadt. Tübingen 1971.

\section{Viri}

Catalogue of books printed in the German-speaking countries and of German books printed in other countries from 1601 to 1700 now in the British Library. London 1994, vol. 1-5.

Kropatschek, J., Oesterreichs Staatsverfassung 4. Wien: Johann Georg Edlen von Mössle, 1796.

Short-title catalogue of books printed in Italy and of Italian books printed in other countries from 1465 to 1600 now in the British Library. London 1988.

Short-title catalogue of books printed in the German-speaking countries and German books printed in other countries from 1455 to 1600 now in the British Museum. London 1962. 


\section{Anja Dular \\ Vloga žensk v črni umetnosti: prve slovenske knjige in zgodovina tiskarstva v Sloveniji}

Ključne besede: ženske, zgodovina tiskarstva, Slovenija

Dovoljenja za ustanovitev tiskarne je izdajala državna administracija. Poleg splošnih pogojev je bila predpisana tudi izobrazba, ki so jo morali imeti tiskarji. Ženske teh pogojev seveda niso mogle izpolnjevati, a jih kljub vsemu najdemo na vodilnih mestih tiskarn in knjigarn. Po določilih dednega prava so namreč po tiskarjevi smrti podedovale tako tiskarne kakor tudi pravico do opravljanja obrti. V članku so predstavljene ženske, ki so vodile tiskarne na Slovenskem oziroma so bile povezane s slovenskimi tiski od 16. do 19. stoletja. Izpostavimo lahko vsaj štiri, ki so s svojim delom prispevale $\mathrm{k}$ razvoju tiskarstva.

Leta 1554 je v Tübingenu umrl tiskar Ulrich Morhart. Nasledila ga je vdova Magdalena Morhart in v obdobju, ko je bila na čelu tiskarne, je natisnila sedemnajst slovenskih knjig.

Leta 1678 je podružnico svojega salzburškega tiskarskega podjetja v Ljubljani ustanovil Janez Krstnik Mayr. Nasledil ga je sin Jožef Tadej, a že 1695 je bila na čelu tiskarne njegova vdova Ana Barbara Mayr in tako postala prva tiskarka na Kranjskem. Tiskarno je uspešno vodila celo desetletje - do leta 1705.

Sredi 18. stoletja je tedaj še vedno edino tiskarno v deželi podedovala Ana Elizabeta Reichard. Vodila jo je le dve leti - 1757-1759 - in v tem času tiskala knjige v štirih jezikih - slovenščini, nemščini, latinščini in italijanščini.

Rozalija Eger je imela pomembno vlogo pri razvoju tiskarstva na naših tleh v 19. stoletju. Leta 1829 je ovdovela in prevzela tiskarno, ki jo je vodila vse do smrti leta 1871. Rozalija Eger je tiskala v treh jezikih - slovenščini, nemščini in latinščini. 


\title{
Anja Dular
}

\section{The History of Printing in Slovenia - The Role of Women in the Black art and the first Slovenian Books}

\author{
Keywords: Women, History of printing, Slovenia
}

Granting permission for setting up a printing house was the prerogative of the state administration, which also granted licenses for the manufacture of the typesets. Although women were clearly unable to meet all of these requirements they worked as heads of bookshops and printing houses. This was due to the fact that after a printer died his legal heirs, generally his widow, inherited the company with all its concessions. In this paper we discuss women connected with Slovene books and books printed in Slovenia from the $16^{\text {th }}$ to $19^{\text {th }}$ centuries.

After Ulrich Morhart's death in Tübingen in 1554 his widow, Magdalena Morhart, continued to run the printing house. It is possible to conclude that as many as seventeen Slovene publications from the $16^{\text {th }}$ century were printed during the period when Magdalena was at the head of the printing house. In 1678 Johannes Baptist Mayr, a printer from Salzburg established in Ljubljana a branch of his printing house in Salzburg. In 1695 his son Joseph Taddeus Mayr was followed by Ana Barbara Mayr, who thus became the first female printer in Carniola. She remained at the head of the printing house for a full decade, until 1705. In the middle of $18^{\text {th }}$ century Anna Elisabetha Reichard inherited the only printing house in Carniola. During the two years - 1757 to 1759 she printed publications in four languages: in Slovene, German, Latin, and Italian. Rosalia Eger played an important role in the development of printing activities in the $19^{\text {th }}$ century. She became a widow in 1829 and took over the printing house which she formally led until her death in 1871. Rosalia Eger printed materials in three languages, namely in Slovene, German, and Latin. 